\title{
ASSESSING EMPATHIC ATTITUDES IN MEDICAL STUDENTS: THE RE-VALIDATION OF THE JEFFERSON SCALE OF EMPATHY- STUDENT VERSION REPORT
} OCENJEVANJE EMPATIČNE NARAVNANOSTI PRI ŠTUDENTIH MEDICINE: POROČILO O PONOVNI VALIDACIJI JEFFERSONOVE LESTVICE EMPATIJE OBLIKA ZA ŠTUDENTE

\author{
Marija PETEK ŠTER ${ }^{1}$, Polona SELIČ ${ }^{1 *}$ \\ 'University of Ljubljana, Faculty of Medicine, Department of Family Medicine, \\ Poljanski nasip 58, 1000 Ljubljana, Slovenia
}

Received/Prispelo: Mar 23, 2015

Original scientific article/Izvirni znanstveni članek

Accepted/Sprejeto: May 18, 2015

\begin{abstract}
Introduction. Self-reported scales, such as the Jefferson Scale of Empathy - Student version (JSE-S), had been

Keywords:

empathy, attitude, values, medical students, self-assessment recognised to measure the empathic disposition rather than behavioural expression. This study aimed to re-validate the JSE-S and its factor structure prior further research on empathy in medical students.

Methods. A convenience sampling method was employed in two consecutive academic years, in 2012/13 and 2013/14, at the Faculty of Medicine in Ljubljana, Slovenia; first and final year students participated voluntarily. The JSE-S examined empathy levels. The principal component analysis was performed with Oblimin rotation and Kaisers' criteria. Factors with eigenvalues $\geq 1.25$ were retained and items loading $\geq|0.40|$ were required for the interpretation of the factor structure.
\end{abstract}

\section{IZVLEČEK}

Ključne besede: empatija stališča, vrednote, študenti medicine, samoocena
Results. The total study sample size was 845 students, $(580(68.6 \%))$ of them women; $327(72.2 \%)$ were in the first $(19.2 \pm 1.9$ years old $)$ and $253(61.7 \%)$ in the sixth $(24.9 \pm 1.1$ years old) year of medical school. Females achieved higher JSE-S scores in all groups.

The three-factor JSE-S was confirmed, but only seven items were concordant in all groups. A higher proportion of explained variation for Perspective Taking and Standing in the Patient's Shoes, and better internal consistency, was found in a reduced-item scale (16-18 items). When performing factor analysis of a seven-item scale, the percentages of explained variance increased with two factors extracted.

Conclusions. Only the cognitive dimension of JSE-S gave results as expected, therefore proper terminology, i.e. the object of assessment, must be used in further administration of JSE-S and empathy-related research in medical students.

Izhodišča. Samoocenjevalne lestvice, kakršna je Jeffersonova lestvica empatije - oblika za študente (JSE-S), so se izkazale kot mere naravnanosti (stališč) in ne kot pripomočki za oceno in napoved vedenja. Zato je bilo treba pred nadaljnjimi raziskavami empatične naravnanosti pri študentih in preučevanjem odnosa med študijskim programom ter pristopi in empatično naravnanostjo študentov ponovno preveriti veljavnost JSE-S, bolj jasno opredeliti predmet merjenja ter variacije/razlike, povezane s spolom.

Metode. S priložnostnim vzorčenjem v dveh zaporednih študijskih letih (2012/13 in 2013/14) so bili študenti prvega in šestega letnika Medicinske fakultete $v$ Ljubljani povabljeni $k$ anonimnemu in prostovoljnemu sodelovanju. Svojo empatično naravnanost so ocenjevali z JSE-S. S Student $t$-testom za neodvisne vzorce in enosmerno analizo variance so bile izračunane razlike po spolu in letniku študija. Vsi testi so bili dvosmerni, z mejo statistične pomembnosti $P<0,05$. Izvedena je bila validacija lestvice po metodi glavnih komponent $\mathrm{z}$ rotacijo Oblimin, ob upoštevanju Kaiserjevih meril. Nasičenost posameznih trditev $\geq|0,40|$ in faktorji z lastno vrednostjo $\geq 1,25$ so bili podlaga za razlago faktorske strukture.

Rezultati. Celotni vzorec je vključeval 845 študentov, med njimi je bilo 580 (68,6\%) žensk, 327 (72,2\%) je bilo študentov prvega letnika, starih 19,2 $\pm 1,9$ leta, 253 (61,7\%) pa študentov šestega letnika, starih 24,9 $\pm 1,1$ leta. Ženske so dosegle višje skupne vrednosti na JSE-S v vseh skupinah.

Tri faktorska struktura JSE-S se je potrdila, vendar se je le sedem trditev/postavk ujemalo $v$ vseh štirih skupinah študentov. Ko je bila lestvica skrajšana na 16 oziroma 18 trditev, se je povečal delež pojasnjene variance pri faktorjih upoštevanje zornega kota drugega in zavzemanje pozicije drugega, boljša je bila tudi notranja konsistentnost. $V$ faktorski analizi lestvice s sedmimi trditvami/postavkami je bil delež pojasnjene variance še večji, ne pa tudi notranja konsistentnost (Cronbach's $a>0,70$ ). Izločena sta bila dva faktorja, oba po vsebini opisujeta kognitivno razsežnost empatije.

Zaključki. Pokazalo se je, da JSE-S meri empatično naravnanost, kar je treba upoštevati $v$ prihodnjih raziskavah ter temu prilagoditi tudi poimenovanje lestvice. Predlagamo uporabo skrajšane lestvice s 16 trditvami, s skupno vrednostjo točk JSE-S kot mero samoocene kognitivne komponente empatije.

*Corresponding author: Tel: +386 31379 707; E-mail: polona.selic@siol.net 


\section{INTRODUCTION}

Empathy refers to an aspect of personality, which has an important role in interpersonal relationships and in facilitating competence in communication. Given that it is considered to be a desirable trait in the medical profession, there have been many trials assessing the level of empathy of students at some point during medical school, or prior to admission $(1,2)$. This past belief that empathy should be based in detached reasoning, without the physician experiencing the patient's emotional state himself/herself $(3,4)$, was probably due to the conviction that empathy is an intellectual, rather than an emotional, form of knowing, as acknowledged by Halpern (2) when describing the function of empathy as the ability to recognize what it feels like to experience something. A definition presented by Stepien and Baernstein (5), describing the meaning of empathy as an understanding or appreciation of how someone else feels, has been broadened for a clinical context to include four aspects, i.e. emotive (the ability to imagine patients' emotions and perspectives), moral (the physician's internal motivation to empathize), cognitive (the intellectual ability to identify and understand patients' emotions and perspectives), and behavioural (the ability to convey understanding of those emotions and perspectives back to the patient). Others have defined empathy mainly at three levels, namely: affective $(6,7)$, cognitive $(8,9)$ and behavioural (8).

In the context of health care, empathy as a predominantly cognitive attribute, combined with the capacity to communicate the understanding of the patient's experiences, concerns, and perspectives and with an intention to help, has been explained and measured by Hojat and co-workers (10). Empathy was found to be likely to enhance patient satisfaction, adherence to therapy, and the willingness to divulge sensitive information that may assist diagnosis (11).

It is important to distinguish empathy, which is nonjudgmental and considered to be manifested consciously (12), from sympathy, an effective response, which lacks a cognitive element and relates more to emotions and the development of feelings for a patient (13). As a component of the physician-patient relationship, empathy has been shown to affect both diagnosis and patient care $(2,14)$. Patients of physicians who had scored high in empathy reported better disease control and prognosis in comparison to patients of physicians with low empathy scores $(10,15)$. Recent empirical evidence suggests empathy is associated with improved clinical outcomes (14) and decreased anxiety in patients $(16,17)$.

\subsection{Enhancing the Empathy of Medical Students}

In Slovenia, similarly to other countries (18), medical students are accepted into medical school primarily on the basis of their achieved academic grades and cognitive skills. However, it has been suggested that effective educational programs might facilitate and improve students' empathic skills (19). For example, more than $80 \%$ of students felt empowered after empathy-based training (20), which gives grounds for assuming that empathy, or at least its cognitive dimension, can be taught. Hojat and co-workers (13) suggested that empathy has evolutionary, genetic, developmental, experiential, situational, and educational roots, and that its deficit could be improved, though not without effort. Early exposure to clinical training and a curriculum for professional competencies was shown to help to enhance the empathy of medical students (21). Empathy can therefore be improved by targeted educational activities (6), and the evidence of a correlation between empathy and clinical outcomes should be made widely known to medical students and their tutors (22-24).

The Slovenian version of the JSE-S has been validated already (25), but further work showed the need to revalidate the scale and provide more a precise definition of the subject in question, based on the limitation of the JSE-S as a measure of empathic disposition, rather than behavioural expression (26). Aside from that, this study aimed, for the first time in Slovenian medical teaching, to assess empathic levels of two generations of first and sixth year medical students, and to examine the variation of empathy during different years of medical education and between genders. The study was also designed to provide the conceptual groundwork to enable further research and evaluation of teaching models aimed at promoting empathy.

\section{METHODS}

\subsection{Participants and Procedure}

A convenience sampling method was employed in two consecutive academic years, 2012/13 and 2013/14, at the Faculty of Medicine in Ljubljana, Slovenia. The first $\left(\mathrm{n}_{2012 / 13}=234, \mathrm{n}_{2013 / 14}=216\right)$ and the final year $\left(\mathrm{n}_{2012 / 13}=219, \mathrm{n}_{2013 / 14}=176\right)$ medical students, attending the compulsory courses 'Communication' and 'Family Medicine,' respectively, were told about the project and its aims following a lecture during the academic schedule in the last week of May, i.e. in May 2013 and May 2014. Of 453 first year students, there were 327 (72.2\%) females and $126(27.8 \%)$ males; in both final year student groups $(n=392)$, there were $253(64.5 \%)$ female and $139(35.5 \%)$ male participants. The students were provided with an explanatory statement and informed that participation was voluntary. The JSE-S, administered to students to examine their self-reported empathy levels, took them approximately ten minutes to complete. Consent was 
implied by the completion and submission of the JSE-S questionnaire, with the response rate in the different groups of students varying from $83.6 \%$ to $98.0 \%$.

\subsection{Measures}

The Jefferson Scale of Physician Empathy (JSPE) and Jefferson Scale of Empathy- Student version (JSE-S) have been used for more than ten years in several settings to measure empathy, not only among undergraduate and graduate students, but also in practicing physicians (2731). For the purpose of this study, the JSE-S, which is a 20item scale designed to measure empathy in the context of patient care and the doctor-patient relationship (28), was administered to examine self-reported empathy levels in students (11). It only takes a few minutes to complete. Students rated their level of empathy for each item on a seven-point Likert scale (1 - strongly disagree, 7 - strongly agree), with higher scores indicating higher levels of empathy. Ten of the items in the JSE-S are positively worded while the other ten are negatively worded, to decrease the confounding effect of the 'acquiescence response style,' i.e. the tendency to constantly agree or disagree (yea-, naysayers). The possible score range is 20-140: the higher the mean score, the higher the selfreported empathy level (28).

A short demographic questionnaire about age, gender and year of study was also included.

\subsection{Data Analysis}

SPSS (IBM SPSS Statistics version 22 for Windows) was used for data storage, tabulation and the generation of descriptive and inferential statistics. The means and standard deviations (SDs) were used to summarize the demographic data. Independent-sample Student's t-tests and one-way analyses of variance were used to compare the differences between gender and years of study. All tests were two-tailed, with the results considered statistically significant if the P-value was $<0.05$.

Following the idea of Tavakol and co-workers (31), a principal component analysis (PCA) was performed to explore the factor structure and the associations between the observed variables (items) and the latent variables (factors). The exploratory nature of the PCA was chosen, as the underlying components of the JSP-S have not yet been thoroughly investigated for Slovenia. An Oblimin rotation with Kaisers' criteria was used to better understand the dimensionality of the JSE-S. Only those factors with eigenvalues of $\geq 1.25$ were retained, and items with a loading of $\geq|0.40|$ were required for the interpretation of the factor structure. Cronbach's alpha coefficient of $>0.70$ was considered as acceptable reliability in determining the internal consistency of the scale.

\section{RESULTS}

\subsection{Gender, Study Year and Scoring of Participants on the JSE-S}

The first year students were $19.2 \pm 1.9$ years old and the sixth year students were $24.9 \pm 1.1$ years old. The total study sample size consisted of 845 students, most of whom were females (580 (68.6\%)); of them $327(72.2 \%)$ were in the first year and $253(61.7 \%)$ in the sixth year. Of males, there were $30.4 \%\left(n_{2012 / 13}=71\right)$ and $25.1 \%\left(n_{2013 / 14}=55\right)$ in first year and $34.3 \%\left(n_{2012 / 13}=74\right)$ and $36.9 \%\left(n_{2013 / 14}=65\right)$ in the last year, respectively.

There were no differences between the groups in the proportion of female students $\left(x^{2}=7.463, p=0.059\right)$. More characteristics are presented in Table 1.

Table 1. JSE-S total scores in the four groups of students.

\begin{tabular}{|c|c|c|c|c|c|c|}
\hline & $\begin{array}{c}\mathrm{N}_{\text {tot }} \\
\text { (response } \\
\text { rate (\%)) }\end{array}$ & $\begin{array}{c}\mathrm{N}_{\text {women }} \\
\text { (\%) }\end{array}$ & $\begin{array}{l}\text { JSE-S } \\
(M \pm S D)\end{array}$ & $\begin{array}{c}\text { JSE-S } \\
(M \pm S D)\end{array}$ & $\begin{array}{l}\text { JSE-S }{ }_{\text {men }} \\
(M \pm S D)\end{array}$ & $P^{*}$ \\
\hline 1 st year students $2012 / 13$ & $234(89.0)$ & $163(69.6)$ & $106.25 \pm 12.21$ & $109.47 \pm 11.79$ & $102.70 \pm 14.00$ & $p=0.001$ \\
\hline 1st year students ${ }_{2013 / 14}$ & $219(83.6)$ & $164(74.9)$ & $110.10 \pm 10.79$ & $112.13 \pm 10.89$ & $107.95 \pm 11.43$ & $p=0.016$ \\
\hline$p^{*}$ & & & $p<0.001$ & $p=0.013$ & $p=0.025$ & \\
\hline 6 th year students ${ }_{2012 / 13}$ & $216(97.3)$ & $142(65.7)$ & $108.64 \pm 12.56$ & $110.07 \pm 12.14$ & $106.20 \pm 12.91$ & $p=0.031$ \\
\hline 6th year students ${ }_{2013 / 14}$ & $176(98.0)$ & $111(63.1)$ & $106.62 \pm 13.34$ & $108.80 \pm 12.13$ & $102.84 \pm 14.55$ & $p=0.007$ \\
\hline$P^{*}$ & & & $p=0.124$ & $p=0.468$ & $p=0.296$ & \\
\hline
\end{tabular}

* Student's t-test 
There were differences in the total score of JSE-S between female and male students $(t=3.652, p=0.001)$. Female students achieved higher JSE-S scores in all groups. There was no difference in the JSE-S scores between first and sixth year students, between female and male students, and male first and sixth year students in the academic year 2012/3, $(t=0.768, p=0.443 ; t=0.442, p=0.673 ; t=$ $0.337, p=0.737$ respectively). There was a difference in the JSE-S scores between the first and sixth year students in the academic year 2013/14 ( $t=2.247, p=0.025)$, yet none when female $(t=1.463, p=0.145)$ and male $(t=0.937$, $\mathrm{p}=0.351$ ) students' scores were tested separately.

\subsection{Results of Confirmatory Factor Analysis}

The three-factor JSE-S was confirmed, with JSE-S giving somewhat better results for the final year medical students, with a higher proportion of explained variation for F1 and F2. The results are presented in Table 2.

Table 2. Confirmatory factor analysis for two generations of first and final year medical students.

\begin{tabular}{|c|c|c|c|c|c|c|}
\hline & $\mathrm{EV}_{\text {total }}(\%)$ & $\mathrm{EV}_{\mathrm{F} 1}(\%)$ & $\mathrm{EV}_{\mathrm{F} 2}(\%)$ & $\mathrm{EV}_{\mathrm{F} 3}(\%)$ & Cronbach's a & $\mathrm{N}$ \\
\hline First year students ${ }_{2012 / 13}$ & 38.600 & 23.913 & 6.753 & 7.936 & 0.790 & 234 \\
\hline First year students $_{2013 / 14}$ & 36.983 & 21.798 & 7.786 & 7. 399 & 0.776 & 219 \\
\hline Sixth year students ${ }_{2012 / 13}$ & 45.824 & 29.849 & 8.934 & 7.041 & 0.789 & 216 \\
\hline Sixth year students $_{2013 / 14}$ & 41.314 & 24.817 & 8.880 & 7.617 & 0.767 & 176 \\
\hline
\end{tabular}

EV (\%): \% of explained variance, $\mathrm{F}$ : factor

F1 - Perspective Taking, F2 - Standing in the Patient`s Shoes, F3 - Compassionate Care

Items with a loading of $\geq|0.40|$ were included in the factor analysis with an Oblimin rotation (eigenvalue $\geq$ 1.25) for each group of students. The results are presented in Table 3. In all four groups of students, the item with a loading of $<|0.40|$ was \#18. In both groups of sixth year students, items \#1 and \#5 loaded to less than $|0.40|$ and were excluded from further analysis. The proportion of explained variance with the reduced number of items (from 16 to 18) was higher in all groups of students (Table 3), compared to the proportion of explained variance in the 20-item scale (Table 2). The internal consistency was better for the reduced-item scale (Cronbach's $\alpha=0.813$ vs. 0.790 in first year students ${ }_{2012 / 13}$, Cronbach's $\alpha=0.774$ vs. 0.776 in first year students ${ }_{2013 / 14}$, Cronbach's $\alpha=0.806$ vs. 0.789 in sixth year students ${ }_{2012 / 13}$, Cronbach's $\alpha=0.785$ vs.0.767 in sixth year students s013/14 ), indicating that the scales demonstrate adequate scale reliability. 
Table 3. Factors with Items loading $\geq|0.40|$ (PCA, Oblimin rotation (eigenvalue $\geq 1.25)$ ) for each group of students.

\begin{tabular}{|c|c|c|c|c|c|}
\hline Item & & $\begin{array}{l}\text { First year } \\
\text { students }_{2012 / 13}\end{array}$ & $\begin{array}{c}\text { First year } \\
\text { students }_{2013 / 14}\end{array}$ & $\begin{array}{l}\text { Sixth year } \\
\text { students }_{2012 / 13}\end{array}$ & $\begin{array}{l}\text { Sixth year } \\
\text { students } \\
\text { s013/14 }\end{array}$ \\
\hline 1 & $\begin{array}{l}\text { Physicians' 'understanding of their patients' feelings and } \\
\text { the feelings of their patients' families does not influence } \\
\text { medical or surgical treatment. }\end{array}$ & -0.513 & 0.417 & I & I \\
\hline 2 & $\begin{array}{l}\text { Patients feel better when their physicians understand } \\
\text { their feelings. }\end{array}$ & 0.623 & I & 0.614 & 0.413 \\
\hline 3 & $\begin{array}{l}\text { It is difficult for a physician to view things from the } \\
\text { patient's perspective. }\end{array}$ & 0.836 & 0.763 & 0.785 & 0.791 \\
\hline 4 & $\begin{array}{l}\text { Understanding body language is as important as verbal } \\
\text { communication in physician-patient relationships. }\end{array}$ & 0.429 & 0.455 & 0.578 & 0.616 \\
\hline 5 & $\begin{array}{l}\text { A physician's sense of humour contributes to a better } \\
\text { clinical outcome. }\end{array}$ & I & 0.452 & 0.492 & I \\
\hline 6 & $\begin{array}{l}\text { Because people are different, it is difficult to see things } \\
\text { from the patient's perspective. }\end{array}$ & 0.815 & 0.725 & 0.781 & 0.809 \\
\hline 7 & $\begin{array}{l}\text { Attention to patients' emotions is not important in } \\
\text { history-taking. }\end{array}$ & -0.510 & 0.587 & 0.589 & I \\
\hline 8 & $\begin{array}{l}\text { Attentiveness to patients' personal experiences does not } \\
\text { influence treatment outcomes. }\end{array}$ & -0.581 & 0.474 & 0.667 & 0.582 \\
\hline 9 & $\begin{array}{l}\text { Physicians should try to stand in their patients' shoes } \\
\text { when providing care to them. }\end{array}$ & 0.613 & 0.709 & 0.538 & 0.702 \\
\hline 10 & $\begin{array}{l}\text { Patients value a physician's understanding of their } \\
\text { feelings which is therapeutic in its own right. }\end{array}$ & 0.444 & 0.524 & 0.549 & 0.517 \\
\hline 11 & $\begin{array}{l}\text { Patients' illnesses can be cured only by medical or } \\
\text { surgical treatment; therefore, physicians' emotional ties } \\
\text { with their patients do not have a significant influence on } \\
\text { medical or surgical treatment. }\end{array}$ & -0.528 & 0.605 & 0.759 & -0.552 \\
\hline 12 & $\begin{array}{l}\text { Asking patients about what is happening in their personal } \\
\text { lives is not helpful in understanding their physical } \\
\text { complaints. }\end{array}$ & -0.573 & 0.726 & 0.718 & -0.782 \\
\hline 13 & $\begin{array}{l}\text { Physicians should try to understand what is going on in } \\
\text { their patients' minds by paying attention to their non- } \\
\text { verbal cues and body language. }\end{array}$ & 0.562 & 0.677 & 0.619 & 0.533 \\
\hline 14 & $\begin{array}{l}\text { I believe that emotion has no place in the treatment of } \\
\text { medical illness. }\end{array}$ & -0.619 & 0.491 & 0.660 & -0.782 \\
\hline 15 & $\begin{array}{l}\text { Empathy is a therapeutic skill, without which the } \\
\text { physician's success is limited. }\end{array}$ & 0.633 & 0.635 & 0.705 & 0.583 \\
\hline 16 & $\begin{array}{l}\text { Physicians' understanding of the emotional status } \\
\text { of their patients, as well as that of their families, is } \\
\text { one important component of the physician-patient } \\
\text { relationship. }\end{array}$ & 0.683 & 0.588 & 0.527 & 0.676 \\
\hline 17 & $\begin{array}{l}\text { Physicians should try to think like their patients in order } \\
\text { to render better care. }\end{array}$ & 0.698 & 0.731 & 0.559 & 0.616 \\
\hline 18 & $\begin{array}{l}\text { Physicians should not allow themselves to be influenced } \\
\text { by strong personal bonds between their patients and their } \\
\text { family members. }\end{array}$ & I & I & I & I \\
\hline 19 & I do not enjoy reading non-medical literature or the arts. & -0.572 & I & 0.480 & -0.476 \\
\hline 20 & $\begin{array}{l}\text { I believe that empathy is an important therapeutic factor } \\
\text { in medical treatment. }\end{array}$ & 0.684 & 0.561 & 0.730 & 0.719 \\
\hline $\mathrm{N}($ items $)$ & & 18 & 17 & 18 & 16 \\
\hline EV (\%) & & 42.527 & 41.759 & 44.648 & 48.905 \\
\hline
\end{tabular}

/: items loading < $|0.40|, \mathrm{EV}(\%)$ : \% of explained variance with reduced number of items 
In Table 4, the loadings of the items in the factor analysis performed in all groups of students are presented.

Table 4. A comparison of items loading to the particular factors in first and final year medical students.

\begin{tabular}{|c|c|c|c|c|c|c|c|c|}
\hline & \multicolumn{2}{|c|}{$\begin{array}{c}\text { First year } \\
\text { students }_{2012 / 13}\end{array}$} & \multicolumn{2}{|c|}{$\begin{array}{c}\text { First year } \\
\text { students }_{2013 / 14}\end{array}$} & \multicolumn{2}{|c|}{$\begin{array}{c}\text { Sixth year } \\
\text { students }_{2012 / 13}\end{array}$} & \multicolumn{2}{|c|}{$\begin{array}{c}\text { Sixth year } \\
\text { students }_{2013 / 14}\end{array}$} \\
\hline & Item \# & Loading & Item \# & Loading & Item \# & Loading & Item \# & Loading \\
\hline F1 & 2 & 0.623 & 1 & 0.417 & 7 & 0.589 & 2 & 0.413 \\
\hline F1 & 4 & 0.429 & 4 & 0.455 & 8 & 0.667 & 4 & 0.616 \\
\hline F1 & 9 & 0.613 & 5 & 0.452 & 10 & 0.549 & 9 & 0.702 \\
\hline F1 & 10 & 0.444 & 9 & 0.709 & 11 & 0.759 & 10 & 0.517 \\
\hline F1 & 13 & 0.562 & 10 & 0.534 & 12 & 0.718 & 12 & -0.782 \\
\hline F1 & 15 & 0.633 & 13 & 0.677 & 13 & 0.619 & 13 & 0.533 \\
\hline F1 & 16 & 0.683 & 15 & 0.724 & 14 & 0.660 & 15 & 0.583 \\
\hline F1 & 17 & 0.698 & 16 & 0.588 & 15 & 0.705 & 16 & 0.676 \\
\hline F1 & 20 & 0.684 & 17 & 0.721 & 16 & 0.527 & 17 & 0.616 \\
\hline F1 & & & 20 & 0.561 & 19 & 0.480 & 20 & 0.719 \\
\hline F1 & & & & & 20 & 0.730 & & \\
\hline F2 & 3 & 0.836 & 3 & 0.763 & 3 & 0.785 & 3 & 0.719 \\
\hline F2 & 6 & 0.815 & 6 & 0.725 & 6 & 0.781 & 6 & 0.809 \\
\hline F3 & 1 & -0.513 & 7 & 0.587 & 2 & 0.441 & 8 & 0.582 \\
\hline F3 & 7 & -0.510 & 8 & 0.474 & 4 & 0.525 & 11 & -0.552 \\
\hline F3 & 8 & -0.581 & 11 & 0.605 & 5 & 0.437 & 12 & -0.782 \\
\hline F3 & 11 & -0.528 & 12 & 0.726 & 9 & 0.526 & 14 & -0.782 \\
\hline F3 & 14 & -0.619 & 14 & 0.491 & 17 & -0.560 & 19 & -0.476 \\
\hline F3 & 17 & 0.698 & & & & & & \\
\hline F3 & 19 & -0.572 & & & & & & \\
\hline
\end{tabular}

F1 - Perspective Taking, F2 - Standing in the Patient`s Shoes, F3 - Compassionate Care

Only seven items were identified as loading to the same factor, i.e. items \#3, \#6, \#10, \#13, \#15, \#16 and \#20 (bolded in Table 4). Perspective Taking (F1) was loaded with the following items: \#10 Patients value a physician's understanding of their feelings, which is therapeutic in its own right. \#13 Physicians should try to understand what is going on in their patients' minds by paying attention to their non-verbal cues and body language. \#15 Empathy is a therapeutic skill without which the physician's success is limited. \#16 Physicians' understanding of the emotional status of their patients, as well as that of their families, is one important component of the physician-patient relationship. \#20 I believe that empathy is an important therapeutic factor in medical treatment. The remaining two items (\#3 It is difficult for a physician to view things from the patient's perspective. \#6 Because people are different, it is difficult to see things from the patient's perspective.) loaded to Standing in the Patient's Shoes (F2). No items loaded to Compassionate Care (F3) and this was true in all groups of students.

In Table 5, the scoring on the JSE-S scale containing items identified in all four groups of students (7-item scale) is presented. Statistically significant differences between male and female JSE-S scores were identified. 
Table 5. Scoring on JSE-S scale containing items identified in all four groups of students (7-item scale).

\begin{tabular}{|c|c|c|c|c|c|c|}
\hline & $\begin{array}{l}\text { First year } \\
\text { students }_{2012 / 13}\end{array}$ & $\begin{array}{c}\text { First year } \\
\text { students }_{2013 / 14}\end{array}$ & p & $\begin{array}{l}\text { Sixth year } \\
\text { students }_{2012 / 13}\end{array}$ & $\begin{array}{l}\text { Sixth year } \\
\text { students }_{2013 / 14}\end{array}$ & $\mathrm{p}^{*}$ \\
\hline $\begin{array}{l}\text { JSE-S }{ }_{\text {total }} \\
(M \pm S D)\end{array}$ & $37.69 \pm 5.45$ & $38.69 \pm 4.90$ & 0.043 & $37.23 \pm 5.50$ & $36.05 \pm 6.04$ & 0.045 \\
\hline $\begin{array}{l}\text { JSE-S } \\
(M \pm S D)\end{array}$ & $38.40 \pm 5.10$ & $39.17 \pm 4.85$ & 0.167 & $37.98 \pm 5.49$ & $37.04 \pm 5.65$ & 0.218 \\
\hline $\begin{array}{l}\text { JSE-S } \\
(M \pm S D)\end{array}$ & $36.04 \pm 5.92$ & $37.04 \pm 4.85$ & 0.313 & $35.90 \pm 5.18$ & $34.33 \pm 6.35$ & 0.119 \\
\hline $\mathrm{p}^{*}$ & 0.002 & 0.005 & & 0.008 & 0.004 & \\
\hline
\end{tabular}

EV (\%): \% of explained variance with reduced number of items

* Student's t-test

When a factor analysis of the 7-item scale was performed, the percentages of explained variance were higher in all groups. Only two factors were extracted, Perspective Taking (F1) and Standing in the Patient's Shoes (F2). These results are presented in Table 6.

Table 6. Confirmatory factor analysis for two generations of first and final year medical students.

\begin{tabular}{|c|c|c|c|c|c|}
\hline & $\mathrm{EV}_{\text {total }}(\%)$ & $\mathrm{EV}_{\mathrm{F} 1}(\%)$ & $\mathrm{EV}_{\mathrm{F} 2}(\%)$ & Cronbach's a & $\mathbf{N}$ \\
\hline First year students ${ }_{2012 / 13}$ & 57.463 & 37.463 & 19.754 & 0.692 & 234 \\
\hline First year students ${ }_{2013 / 14}$ & 54.849 & 34.730 & 20.119 & 0.465 & 219 \\
\hline Sixth year students ${ }_{2012 / 13}$ & 59.409 & 37.186 & 22.223 & 0.634 & 216 \\
\hline Sixth year students ${ }_{2013 / 14}$ & 63.758 & 41.936 & 21.822 & 0.733 & 176 \\
\hline
\end{tabular}

EV (\%): \% of explained variance, $\mathrm{F}$ : factor

F1 - Perspective Taking, F2 - Standing in the Patient's Shoes

Comparing the 18-item scale (Table 3 ) with the 7-item scale, the proportion of explained variance in first year students $_{2012 / 13}$ was $57.22 \%$ vs. $42.53 \%$, and in sixth year students $_{2012 / 13}$ it was even higher, i.e. $59.41 \%$ vs. $44.65 \%$. Comparing the 17-item scale analysis in the first year students $_{2013 / 14}$ with the 7-item scale (Table 5), there was $54.85 \%$ vs. $41.76 \%$ of explained variance, while comparing the 16-item scale analysis in sixth year students ${ }_{2013 / 14}$ with the 7 -item scale, $63.76 \%$ vs. $48.90 \%$ of the total variance was explained. However, the internal consistency (Cronbach's a) was below 0.70 in all groups, except for sixth year students ${ }_{2013 / 14}$ (Table 6).

\section{DISCUSSION}

This study provided revalidation of the JSE-S and results regarding empathic attitudes in undergraduate medical students. By assessing the JSE-S scores in two groups of first and sixth year medical students, and comparing the JSE-S scores in male and female students, the study provided novel findings, with empathy levels in both first year and final year medical students (Table 1) comparable to other authors $(21,31,33)$.

\subsection{JSE-S Scores in the First and Final Year Students}

Contrary to several other authors, who stated that empathic attitudes decrease as the level of medical education increases $(15,32)$, in this study, the students in their final year had similar JSE-S scores to students in first year. Although there was difference in JSE-S scores between the first and sixth year students in the academic year 2013/14, there were none when female and male students' scores were tested separately (Table 1). This is close to the results obtained in Japanese and Korean medical students $(33,34)$. The aforementioned difference in JSE-S scores between the first and sixth year students, 
and also the difference between the two groups of first year students (Table 1), might be due to coincidence, and thus needs to be verified in further research. Similar JSE-S scores recorded in both groups of senior medical students in this study could be a result of cohort effects (35).

There are several pre-existing factors to be taken into consideration with the first year students. Van Ryn and co-workers (36) examined the individual predictors of first semester medical students' attitudes toward the value of physician empathy in clinical encounters, and found students varied in their attitudes towards the value of physician empathy when they start medical school, and that prior attitudes and knowledge have a strong effect on current learning. Therefore, there are innumerable factors that might have contributed to our results (Table $1)$, such as experiences during student placements and mentoring during the study process, which our study failed to examine, as well as other possible influencing factors and personal traits, so our study is limited for generalizing its findings in this domain. It would be of the utmost importance for medical educators in Slovenia to systematically examine the threat of erosion of empathy towards the final study year as reported by others $(6,15,32,37-39)$, at a time when the curriculum is shifting toward patient-care activities where empathy is essential. Klemenc-Ketiš and Vrečko (40), in their study on perceptions of professionalism by 1 st and 5 th year medical students at the Faculty of Medicine in Maribor, reported students of both study years recognising empathy as one of the components of professionalism, yet first-year students expressed a very pragmatic attitude towards the empathic behaviour, whilst fifth-year students were concerned about how to cope with too much empathy, perceiving physicians as more self-centred.

It is important to emphasize that also contextual factors might have affected the results in the first and final year students. Hemmerdinger and co-workers reported the psychometric properties of a test changing according to the context in which it was used (11). In our study, the JSE-S could have behaved differently with the final year medical students if they perceived the results as powerful in affecting their career chances, as opposed to junior medical students.

\subsection{JSE-S Scores in Female and Male Students}

Consistent with many international studies (14, 21, 27, 35,41 ), in our study, female students were found to have higher JSE-S scores than their male peers (Table 1, Table 5). Explanation for these results might be in the traditional and evolutionary role of women as caregivers (27), with females being more perceptive to emotions or males taking a more rational rather than emotive approach (14). Authors of Professionalism Assessment Scale, based on undergraduate medical students' perceptions of, and attitudes towards, professionalism, a newly developed self-assessment tool in Slovenia, in their validation report, also warned results should be interpreted with care, due to gender bias related to self-assed empathic attitudes (42).

\subsection{JSE-S Three Factor Model}

Further analysis showed that the hypothesised threefactor model of the JSE-S structure fitted the study year differences between medical students (Table 2), while the reduced number of items scale (Table 3 ) fitted even better, with a higher proportion of explained variance in most cases, i.e. in first year students ${ }_{2012 / 13} 38.60 \%$ vs. $42.53 \%$, in first year students ${ }_{2013 / 14} 36.98 \%$ vs. $41.76 \%$, sixth year students $\mathrm{t}_{2012 / 13} 45.82 \%$ vs. $44.65 \%$ and in sixth year students $2013 / 1441.31 \%$ vs. $48.90 \%$.

An additional comparison aiming to identify those JSE-S items which loaded to a particular factor (F1: Perspective Taking, F2: Standing in the Patient's shoes, F3: Compassionate Care) in all groups of students (Table 4) resulted in a factor analysis of the7-item scale (Table 5, Table 6). In this study, only seven JSE-S items were shown to load to JSE-S factors in all four groups of students (Table 4, Table 6); of them, five loaded to Perspective Taking (F1) and two loaded to Standing in the Patient's Shoes (F2), both being cognitive dimensions, at least in these authors' understanding. Quince and coworkers (43) reported that affective empathy in medical students slightly but significantly declined in both the undergraduate and clinical phases, though cognitive empathy was unchanged, while neither affective nor cognitive empathy changed among females. Given that, the results from this study (Table 1 , Table 5) suggesting that empathic attitudes did not decrease during the study process, could also be explained.

Students lacking real-life experience in clinical settings had probably not experienced in-depth caring and compassion. Their JSE-S scores mainly reflect Perspective Taking (F1) and Standing in the Patients' Shoes (F2), while Compassionate Care, as an affective dimension (F3), explained the smallest proportion of total variance in each group (Table 2). Moreover, when analysing the content of the concordant seven items in all the groups of students (Table 4), they express (social) attitudes, defined as 'enduring, learned predispositions to behave in a consistent way toward a given class of objects, or a persistent mental and/or neural state of readiness to react to a certain class of objects, not as they are, but as they are conceived to be' (44). Therefore, it would be fair to conclude that when reducing the number of JSE-S scale items and explaining the higher proportion of variance (Table 5, Table 6), we assessed attitudes and not empathy, defined as the 'individual's objective and insightful awareness of the feelings and behaviour of another 
person, which includes caring, and is the demonstration of an awareness of and a concern for the good of others' (45) in medical students. As such, in our opinion, these assessments (the JSE-S scores) reflect and are closer to values, i.e. 'abstract standards or empirical variables in social life which are believed to be important and/or desirable' (46) than they are to emotions, i.e. 'affective states which can be experienced and have arousing and motivational properties' (47).

One of the strengths of this study is that it included an appropriate sample size, which represents $89.0 \%$, 83.6\% $97.3 \%$ and $98.0 \%$ of the population of first year students $\mathrm{2012/13}$, first year students s013/14 , sixth year students $\mathrm{s}_{2012 / 13}$ and sixth year students 2013/14 , respectively (Table 1). Our research is the first of its kind in Slovenia and assessed multiple variables, such as age, gender and year of education.

Based on the results of this study, we should be somewhat restrained about the measurement of the multi-dimensional concept of empathy, given that JSE-S measure solely empathic attitudes in medical students. Therefore, our suggestion would be to use 16-items scale and JSE-S total score as a measure of empathic attitude in medical students in further research. Items \#1, 5, 18 and 19 are to be left out of the scoring.

\subsection{Implications for Future Research}

It would be valuable to carry out a prospective study, in which students would be followed annually, from the beginning of their first year until graduation, to give a true representation of any changes in empathic attitudes. Ideally, future study design should also include postqualification measurements, with other variables, such as cultural background, and specialty preferences included.

\subsection{Limitations to the Study}

There were several limitations to our research. The study was cross-sectional with two consecutive data collection periods (May 2013 and May 2014), and the nature of the study enabled the authors to examine empathy levels in first and final year medical students. However, we were unable to control clinical placement experience, or the level of empathy training, or assessment they had received.

Additionally, self-reported measures, such as the JSE-S version, have respondent bias and, in no way, reflect what might occur in actual clinical practice. Only patientperceived empathy has been shown to be significantly related to patient outcomes $(32,38)$. Another limitation of self-reported data worth mentioning is the limited validity of the findings, as the respondents, for various reasons, might have under- or overestimated the practice of empathy, with the person's own self-perception influencing their choices while filling out the questionnaire; consequently, this may vary from the actual behaviour that is implemented in their everyday interactions. A methodological problem frequently associated with the use of self-report measures, which may have been evident in the present study, is an inability to determine the extent to which the responses accurately reflect the respondents' experiences and expectations of their empathy, due to social desirability and inaccurate recall. Therefore, in clinical settings, it appears best to use a patient-perceived empathy scale to measure physician empathy in practice.

\section{CONCLUSIONS}

In our opinion, the JSE-S scores recorded in the four groups of students mostly reflect their attitudes and not empathy in its multidimensional meaning. Future assessments need to be based on JSE-S 16-items scale with total scores as a measure of cognitive dimension of empathy. Further research is also needed to determine whether our results are related to cultural peculiarities, the adaptation of the scale, or sampling.

\section{ABBREVIATIONS}

EV (\%): \% of explained variance

F1 - Perspective Taking, F2 - Standing in the Patient's Shoes, F3 - Compassionate Care

\section{CONFLICTS OF INTEREST}

The authors declare no conflicts of interest.

\section{ACKNOWLEDGEMENTS AND FUNDING}

We are grateful to the GPs and patients who took part in the study. Special thanks to Ms. Justi Carey for her language corrections and Mr. Alojz Tapajner for his advice on data presentation.

The study was partly supported by the Slovenian Research Agency, Research Programme Code P3-0339.

\section{ETHICAL APPROVAL}

The research protocol was approved by the Commission of the Republic of Slovenia for Medical Ethics, decision number 143/02/11, on January 31, 2011. 


\section{AUTHORS' CONTRIBUTIONS}

MPS conceived the study, carried out the execution of the study and performed data analysis. PS helped to plan the study and drafted the manuscript. Both authors read and approved the final manuscript.

\section{AUTHORS' INFORMATION}

MPS: Ph.D. Family Medicine, Associate Professor at the Department of Family Medicine

PS: Ph.D. Clinical Psychology, Associate Professor and Senior Researcher at the Department of Family Medicine.

\section{REFERENCES}

1. Marley J, Carmen I. Selecting medical students: a case report of the need for change. Med Educ 1999; 33: 455-9.

2. Halpern J. What is clinical empathy? J Gen Intern Med 2003; 18: 670-4.

3. Aring C. Sympathy and empathy. JAMA 1958; 167: 448-52.

4. Blumgart H. Caring for the patient. N Engl J Med 1964; 270: 449-56.

5. Stepien KA, Baernstein A. Educating for empathy. J Gen Intern Med 2006; 21: 524-30.

6. Shapiro J. How do physicians teach empathy in the primary care setting? Acad Med 2002; 77: 323-8.

7. Suchman AL, Markakis K, Beckman HB, Frankel R. A model of empathic communication in the medical interview. JAMA 1997; 277: 678-82.

8. Irving P, Dickson D. Empathy: towards a conceptual framework for health professionals. Int J Health Care Qual Assur Inc Leadersh Health Serv 2004; 17: 212-20.

9. Norfolk T, Birdi K, Walsh D. The role of empathy in establishing rapport in the consultation: a new model. Med Educ 2007; 41: 690-7.

10. Hojat M, Louis DZ, Markham FW, Wender R, Rabinowitz C, Gonnella JS. Physicians' empathy and clinical outcomes for diabetic patients. Acad Med 2011; 86: 359-64.

11. Hemmerdinger JM, Stoddart SD, Lilford RJ. A systematic review of tests of empathy in medicine. BMC Med Educ 2007; 7: 24.

12. Suh D, Hong J, Lee D, Gonnella J, Hojat M. The Jefferson Scale of Physician Empathy: a preliminary psychometric study and group comparisons in Korean physicians. Med Teach 2012; 34: e464-8.

13. Hojat M, Louis DZ, Maio V, Gonnella JS. Empathy and health care quality. Am J Med Qual 2013; 28: 6-7.

14. Williams B, Brown T, McKenna L, Boyle MJ, Palermo C, Nestel D. et al. Empathy levels among health professional students: a crosssectional study at two universities in Australia. Adv Med Educ Pract 2014; 5: 107-13.

15. Tavakol S, Dennick R, Tavakol M. Medical students' understanding of empathy: a phenomenological study. Med Educ 2012; 46: 306-16.

16. Butow P, Maclean M, Dunn S, Tattersall M, Boyer M. The dynamics of change: cancer patients' preferences for information, involvement and support. Ann Oncol 1997; 8: 857-63.

17. Rietveld $S$, Prins P. The relationship between negative emotions and acute subjective and objective symptoms of childhood asthma. Psychol Med 1998; 28: 407-15.

18. MCManus IC, Powis DA, Wakeford R, Ferguson E, James D, Richards P. Intellectual aptitude tests and A levels for selecting UK school leaver entrants for medical school. BMJ 2005; 331: 555-9.
19. Ozcan CT, Oflaz F, Bakir B. The effect of a structured empathy course on the students of a medical and a nursing school. Int Nurs Rev 2012; 59: 532-8.

20. Regehr C, Goldberg G, Hughes J. Exposure to human tragedy, empathy, and trauma in ambulance paramedics. Am J Orthopsychiatry 2002; 72: 505-13.

21. Wen D, Ma X, Li H, Liu Z, Xian B, Liu Y. Empathy in Chinese medical students: psychometric characteristics and differences by gender and year of medical education. BMC Med Educ 2013; 13: 130.

22. Neumann M, Bensing J, Mercer S, Ernstmann N, Ommen O, Pfaff H. Analyzing the 'nature' and 'specific effectiveness' of clinical empathy: a theoretical overview and contribution towards a theorybased research agenda. Patient Educ Couns 2009; 74: 339-46.

23. Treadway K, Chatterjee N. Into the water- the clinical clerkships. N Engl J Med 2011; 364: 1190-3.

24. Hojat $M$. Ten approaches for enhancing empathy in health and human services cultures. J Health Hum Serv Adm 2009; 31:412-50.

25. Petek-Ster M, Ster B, Petek D, Cedilnik-Gorup E. Validation of Slovenian version of Jefferson scale of empathy for students. Zdrav Var 2013; 53: 89-100.

26. Hojat M. Empathy in patient care: antecedents, development, measurement, and outcomes. New York: Springer, 2007: 112-3

27. Hojat M, Gonnella JS, Nasca TJ, Mangione S, Vergare M, Magee M. Physician empathy: definition, components, measurement, and relationship to gender and specialty. Am J Psychiatry 2002; 159: 1563-9.

28. Hojat M, Mangione S, Nasca T, Cohen M, Gonnella J, Erdmann J. et al. The Jefferson Scale of Empathy: development and preliminary psychometric data. Med Educ 2002; 36: 522-7.

29. Di Lillo M, Cicchetti A, Lo Scalzo A, Taroni F, Hojat M. The Jefferson Scale of Physician Empathy: preliminary psychometrics and group comparisons in Italian physicians. Acad Med 2009; 84: 1198-202.

30. Bellini LM, Baime M, Shea JA. Variation of mood and empathy during internship. JAMA 2002; 287: 3143-6.

31. Tavakol S, Dennick R, Tavakol M. Psychometric properties and confirmatory factor analysis of the Jefferson Scale of Physician Empathy. BMC Med Educ 2011, 11: 54.

32. Pedersen R. Empirical research on empathy in medicine: a critical review. Patient Educ Couns 2009, 76: 307-22.

33. Kataoka HU, Koide N, Ochi K, Hojat M, Gonnella JS. Measurement of empathy among Japanese medical students: psychometrics and score differences by gender and level of medical education. Acad Med 2009; 84: 1192-7.

34. Roh MS, Hahm BJ, Lee DH, Suh DH. Evaluation of empathy among Korean medical students: a cross-sectional study using the Korean version of the Jefferson Scale of Physician Empathy. Teach Learn Med 2010, 22: 167-71.

35. Bangash AS, Ali NF, Shehzad AH, Haqqi S. Maintenance of empathy levels among first and final year medical students: a cross sectional study. F1000 Res 2013, 2: 157.

36. van Ryn M, Hardeman RR, Phelan SM, Burke SE, Przedworski J, Allen $M L$. et al. Psychosocial predictors of attitudes toward physician empathy in clinical encounters among 4732 first year medical students: a report from the CHANGES study. Patient Educ Couns 2014; 96: 367-75.

37. Hojat M, Vergare MJ, Maxwell K, Brainard G, Herrine SK, Isenberg GA. et al. The devil is in the third year: a longitudinal study of erosion of empathy in medical school. Acad Med 2009; 84: 1182-91.

38. Konrath $\mathrm{SH}, \mathrm{O}$ 'Brien $\mathrm{EH}$, Hsing $\mathrm{C}$. Changes in dispositional empathy in American college students over time: a meta-analysis. Pers Soc Psychol Rev 2011; 15: 180-98.

39. Chen D, Lew R, Hershman W, Orlander J. A cross-sectional measurement of medical student empathy. J Gen Intern Med 2007; 22: $1434-8$. 
40. Klemenc-Ketis Z, Vrecko $\mathrm{H}$. The perceptions of professionalism by 1 (st) and 5(th) grade medical students. Acta Inform Med 2014; 22: 292-6.

41. Connor K, King R, Malone KM, Guerandel A. Clinical examiners, simulated patients, and student self-assessed empathy in medical students during a psychiatry objective structured clinical examination. Acad Psychiatry 2014; 38: 451-7.

42. Klemenc-Ketis Z, Vrecko H. Development and validation of a professionalism assessment scale for medical students. Int J Med Educ 2014; 5: 205-11.

43. Quince TA, Parker RA, Wood DF, Benson JA. Stability of empathy among undergraduate medical students: a longitudinal study at one UK medical school. BMC Med Educ 2011; 11:90.

44. National Center for Biotechnology Information. MeSH database. Available February 28, 2015 from: http://www.ncbi.nlm.nih.gov/ mesh/?term=attitude.

45. National Center for Biotechnology Information. MeSH database. Available February 28, 2015 from: http://www.ncbi.nlm.nih.gov/ mesh/?term=empathy.

46. National Center for Biotechnology Information. MeSH database. Available February 28, 2015 from: http://www.ncbi.nlm.nih.gov/ mesh/?term=social+values.

47. National Center for Biotechnology Information. MeSH database. Available February 28, 2015 from: http://www.ncbi.nlm.nih.gov/ mesh/?term=emotions. 